\title{
Modelling tyrosinase monooxygenase activity. Activation of dioxygen by dicopper(I) complexes and characterisation of dicopper(II) complexes
}

\author{
RAJEEV GUPTA, DEBALINA GHOSH and \\ RABINDRANATH MUKHERJEE* \\ Department of Chemistry, Indian Institute of Technology, Kanpur 208 016, \\ India \\ e-mail: rnm@iitk.ac.in
}

\begin{abstract}
Activation of dioxygen on dicopper(I) centres was systematically investigated using a group of open-chain and a macrocyclic $m$-xylyl-based dinucleating ligand from a bioinorganic viewpoint. Even though intermediate peroxodicopper(II) species was not detected (even at $-80^{\circ} \mathrm{C}$ for the open-chain system), the putative intermediate reacted with $\mathrm{C}-\mathrm{H}$ groups in ligands giving oxygenated products (C-OH groups). Absorption, spectroscopic and magnetic properties of the final dicopper(II) complexes have been investigated.
\end{abstract}

Keywords. Dioxygen; dicopper complexes; $m$-xylyl-based dinucleating ligands; stoichiometric oxidation reactions.

\section{Introduction}

The activation of molecular oxygen by copper plays a vital role in synthetically useful stoichiometric and catalytic oxidative conversions of organic molecules and in biological systems ${ }^{1-4}$. Tyrosinase ${ }^{5}$ is a monooxygenase that catalyses $o$-hydroxylation of monophenols and the oxidation of $o$-diphenols to $o$-quinones. Considerable progress has been made in the chemical modelling of tyrosinase-like activity (aromatic ring hydroxylation $)^{1,2,6-16}$. To gain more insight into the reactivity of the binuclear copper(I) complexes with dioxygen and in the dependency of the arene hydroxylation on ligand topology, we have initiated a programme to systematically investigate tyrosinase-like monooxygenase activity using new $m$-xylyl-based dinucleating ligand systems of the open-chain type or of the macrocyclic type, capable of providing only two Ncoordinations to each copper site. Here we provide a brief account of our findings of this exciting chemistry.

\section{Experimental}

Materials and equipment required and methods of preparation/generation of dicopper(I) and isolation of dicopper(II) compounds are described elsewhere ${ }^{17-20}$.

*For correspondence 


\section{Results and discussion}

3.1 Synthesis and characterisation of open-chain ligands and their dicopper(I) complexes ${ }^{17,19}$

The dinucleating ligands (figure 1) were prepared by standard methods. The dicopper(I) complexes of $\mathrm{L}$ (1a) and $\mathrm{L}_{-} \mathrm{NO}_{2}$ (1) $)$ were characterised by IR and ${ }^{1} \mathrm{H} N \mathrm{NR}$ spectroscopy. The ${ }^{1} \mathrm{H}$ NMR spectrum of $\left[\mathrm{Cu}_{2}\left(\mathrm{~L}_{-} \mathrm{NO}_{2}\right)\left(\mathrm{CH}_{3} \mathrm{CN}_{2}\right)\left[\mathrm{SbF}_{6}\right]_{2}(\mathbf{1 b})\right.$ is displayed in figure 2 . The ligand $\mathrm{L} \leq$ (figure 1 ) was synthesised to specifically pinpoint the effect of ligand topology to bring about aromatic ring hydroxylation with our parent $m$-xylyl-based binucleating ligand L. It is to be noted that on coordination while $\mathrm{L}$ gives rise to a sixmembered chelate ring, Lsprovides a five-membered chelate ring.

\subsection{Synthesis of the macrocyclic ligand and its dicopper(I) complex ${ }^{20}$}

The macrocyclic ligand $\mathrm{L}^{\text {mac }}$ (figure 1) was prepared by the Schiff base condensation of 1,2-diaminoethane and isophthalaldehyde in $\mathrm{CH}_{3} \mathrm{CN}$ at $298 \mathrm{~K}$. The dicopper(I) complex of this macrocyclic ligand $\left[\mathrm{Cu}_{2}\left(\mathrm{~L}^{\mathrm{mac}}\right)\left(\mathrm{CH}_{3} \mathrm{CN}\right)_{2}\right]\left[\mathrm{ClO}_{4}\right]_{2}(\mathbf{1 c})$ was prepared under argon from the reaction between the ligand and $\left[\mathrm{Cu}\left(\mathrm{CH}_{3} \mathrm{CN}\right)_{4}\right]\left(\mathrm{ClO}_{4}\right)(1: 2$ ligand-to-metal mole ratio) in $\mathrm{CH}_{2} \mathrm{Cl}_{2}$. The complex was identified by its IR, ${ }^{1} \mathrm{H}$ NMR and FAB-MS spectra.

\subsection{Reactivity of dicopper(I) complexes of open-chain ligands with dioxygen ${ }^{19}$}

The dicopper(I) complexes of $\mathrm{L}$ were exposed to molecular oxygen at $-80^{\circ} \mathrm{C}$ and absorption spectral behaviour was investigated at this temperature. In $\mathrm{CH}_{2} \mathrm{Cl}_{2}$ and THF, the solution of dicopper(I) complexes turned green on exposure and an absorption band appeared at $352 \mathrm{~nm}$, which did not change on warming the solution to room temperature. The peak at $352 \mathrm{~nm}$ is due to $\mathrm{PhO}^{-} / \mathrm{OH}^{-} \rightarrow \mathrm{Cu}$ (II) charge-transfer transition, originating due to the formation of the phenoxo- and hydroxo-bridged dicopper(II) complex (vide infra). As the proposed attack of peroxo-copper(II) intermediate is thought to be electrophilic in nature, we hoped to detect spectroscopically the peroxo species using a $p-\mathrm{NO}_{2}$ derivative of the parent ligand $\mathrm{L}$. We therefore synthesized the ligand $\mathrm{L}-\mathrm{NO}_{2}$ (figure 1) and its dicopper(I) complex $\left[\mathrm{Cu}_{2}\left(\mathrm{~L}-\mathrm{NO}_{2}\right)\left(\mathrm{CH}_{3} \mathrm{CN}\right)_{2}\right]\left[\mathrm{ClO}_{4}\right]_{2}$ (1) $)$. However, when this complex $1 \mathbf{b}$ dissolved in either $\mathrm{CH}_{2} \mathrm{Cl}_{2}$ or THF was exposed to $\mathrm{O}_{2}$ at $-80^{\circ} \mathrm{C}$, we could not detect any peroxo intermediate. The otherwise kinetically favourable
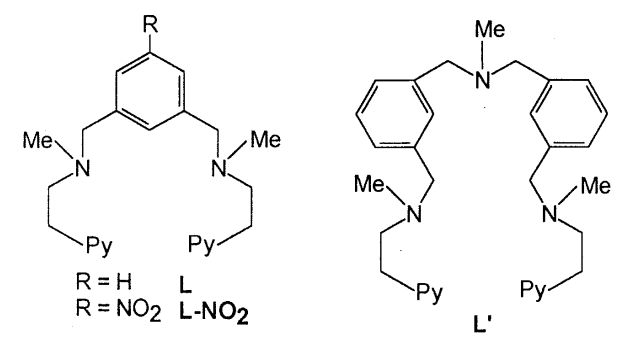

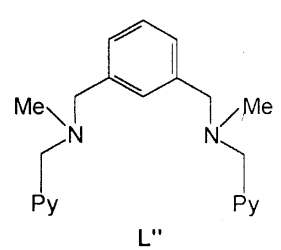

L"<smiles>NCCN=CC=NCCN=Cc1cccc(CN=CC2CCCCC2)c1</smiles>

Lmac

Figure 1. Structure of the ligands used in this study. 


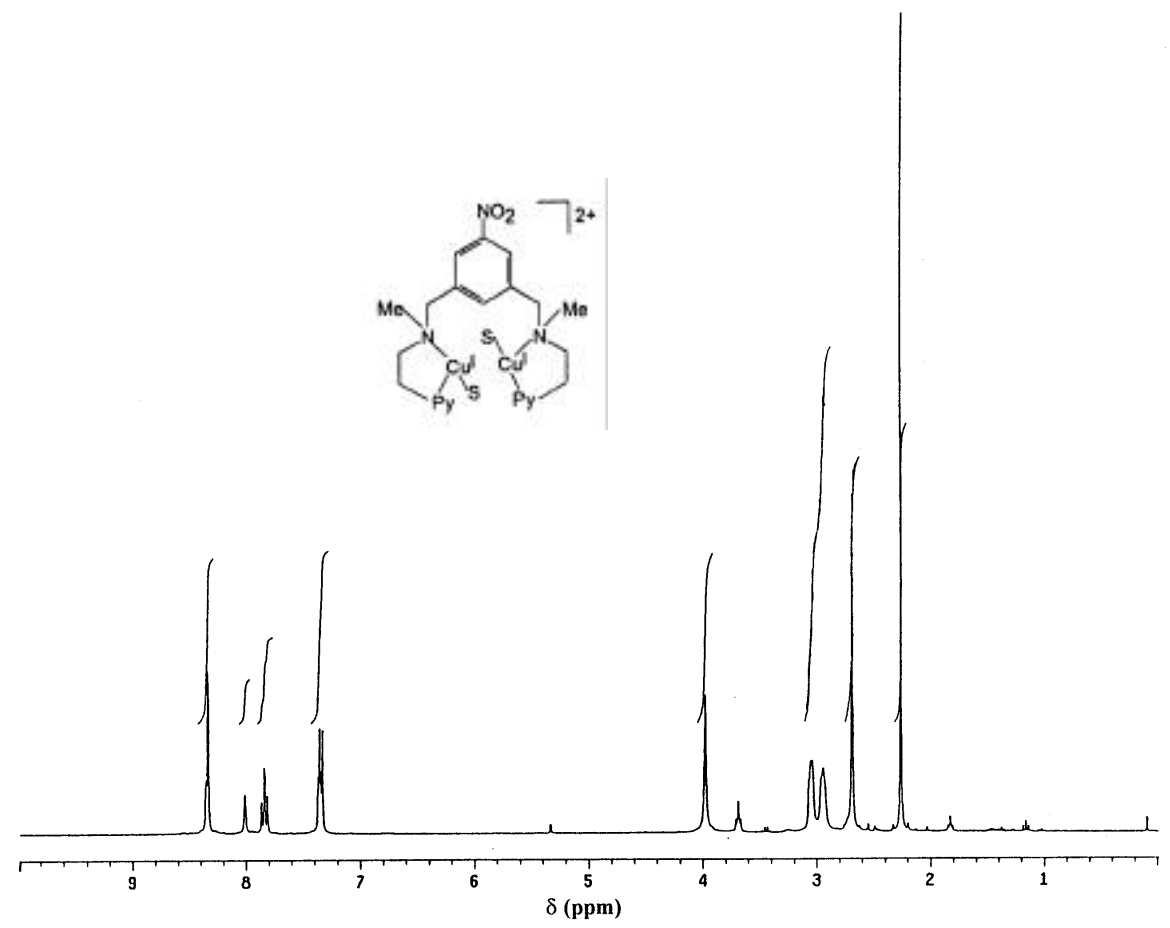

Figure 2. ${ }^{1} \mathrm{H} \mathrm{NMR}(500 \mathrm{MHz})$ spectrum of $\left[\mathrm{Cu}_{2}^{\mathrm{I}}(\mathrm{L})\left(\mathrm{CH}_{3} \mathrm{CN}\right)_{2}\right]\left[\mathrm{SbF}_{6}\right]_{2}$ (1) in $\mathrm{CD}_{2} \mathrm{Cl}_{2}$ at room temperature.

hydroxylation of the aromatic ring was observed. In essence, these results imply that the peroxo intermediate is of insufficient stability to be observed because of the low barrier for its subsequent reaction.

Treatment of $\mathrm{L} \leq$ with 2 equivalents of $\left[\mathrm{Cu}\left(\mathrm{CH}_{3} \mathrm{CN}\right)_{4}\right]\left(\mathrm{ClO}_{4}\right)$ in $\mathrm{CH}_{2} \mathrm{Cl}_{2}$ under dinitrogen at $-60^{\circ} \mathrm{C}$, followed by exposure to dioxygen and slowly warming up the reaction mixture to $298 \mathrm{~K}$, resulted in an immediate colour change of the suspension from yellow to light blue. We confirmed that hydroxylation of the benzene ring of the ligand had not occurred by isolating the ligand from the isolated dicopper(II) complex $\mathrm{Cu}_{2}{ }_{2}$ $\left(\mathrm{L} \Varangle(\mathrm{OH})\left(\mathrm{ClO}_{4}\right)_{3}\left(\mathrm{H}_{2} \mathrm{O}\right)_{2}\right.$. The organic extract has the same ${ }^{1} \mathrm{H}$ NMR spectral feature as that in L $\leq$ All attempts to characterise this copper(II) compound apart from assigning its empirical composition failed.

\subsection{Reactivity of dicopper(I) complex of macrocyclic ligand with dioxygen ${ }^{20}$}

On exposure to dry dioxygen, a suspension of $\left[\mathrm{Cu}_{2}\left(\mathrm{~L}^{\mathrm{mac}}\right)\left(\mathrm{CH}_{3} \mathrm{CN}\right)_{2}\right]\left[\mathrm{ClO}_{4}\right]_{2}$ (1c) in $\mathrm{CH}_{3} \mathrm{OH}-\mathrm{CH}_{3} \mathrm{CN}$ (3:1 vol/vol) generates a bluish-green solid. This solid was dissolved in $6 \mathrm{M} \mathrm{HCl}$ and extraction with $\mathrm{CHCl}_{3}$ produced a yellowish white solid. The peak integration and mass spectral feature of ${ }^{1} \mathrm{H}$ NMR spectrum of this solid in $\mathrm{CDCl}_{3}$ unambiguously revealed that this solid was a mixture of isophthalaldehyde and 2,6diformylphenol. This result demonstrates that due to oxygenation of $\left[\mathrm{Cu}_{2}\left(\mathrm{~L}^{\mathrm{mac}}\right)\right.$ $\left.\left(\mathrm{CH}_{3} \mathrm{CN}\right)_{2}\right]\left[\mathrm{ClO}_{4}\right]_{2}(\mathbf{1 c})$, oxygen insertion into the aromatic ring has occurred with only one of the aromatic rings hydroxylated. 


\subsection{Characterisation of dicopper(II) complexes of open-chain ligands ${ }^{17-19}$}

Initial synthetic reaction of $\mathrm{L}$ (contaminated with $\mathrm{L} \phi$ with $\left[\mathrm{Cu}\left(\mathrm{CH}_{3} \mathrm{CN}\right)_{4}\right]\left(\mathrm{ClO}_{4}\right)$ were carried out in $\mathrm{CH}_{2} \mathrm{Cl}_{2}$ under a dinitrogen atmosphere. It should be noted that initial ligand synthesis of $\mathrm{L}$ had an impurity L\$ the nature of which was identified from X-ray structural analysis of its dicopper(II) compound (vide infra). The synthesis of pure L was achieved subsequently. The yellow solution with a yellow suspension thus obtained was exposed to dioxygen. After $12 \mathrm{~h}$, the reaction mixture turned dark green and afforded green phenoxo- and hydroxo-bridged dicopper(II) complex $\left[\mathrm{Cu}_{2}(\mathrm{~L}-\mathrm{O})(\mathrm{OH})\right]\left[\mathrm{ClO}_{4}\right]_{2}(\mathbf{2 a})$ as the major isolated solution product with a very small amount of light blue dihydroxobridged dicopper(II) complex $\left[\mathrm{Cu}_{2} \mathrm{~L} \notin(\mathrm{OH})\right]\left[\mathrm{ClO}_{4}\right]_{2}(\mathbf{2 b})$.

The X-ray structure of $\left[\mathrm{Cu}_{2}(\mathrm{~L}-\mathrm{O})(\mathrm{OH})\right]\left[\mathrm{ClO}_{4}\right]_{2}$ underscores the incorporation of two $\mathrm{O}$ atoms into the complex: one into the aryl hydrogen bond and the other into the hydroxy bridge. The $\mathrm{X}$-ray structure of $\left.\left[\mathrm{Cu}_{2} \mathrm{~L} \notin \mathrm{OH}\right)_{2}\right]\left[\mathrm{ClO}_{4}\right]_{2}$ reveals that the $\mathrm{Cu}_{2} \mathrm{O}_{2}$ unit is bent (hinge distortion). The structural cores are in figure $3^{17}$. The $\mathrm{X}$-ray structure of 2b revealed the exact nature of the impurity that was present during the initial synthesis of L.

The electronic spectra of $\mathbf{2 a}$ and $\mathbf{2 b}$ in $\mathrm{CH}_{3} \mathrm{CN}$ are displayed in figure 4 and the data are in table 1. For both complexes ligand field band is observed in the range $560-640 \mathrm{~nm}$. The high-energy transitions are due to $\mathrm{PhO}^{-} \rightarrow \mathrm{Cu}$ (II) and/or $\mathrm{OH}^{-} \rightarrow \mathrm{Cu}$ (II) (in the case of $\mathbf{2 a}$ ) and $\mathrm{OH}^{-} \rightarrow \mathrm{Cu}$ (II) (in the case of $\mathbf{2 b}$ ) ligand-to-metal charge-transfer (LMCT) origin.

\subsection{Characterisation of the dicopper(II) complex of macrocyclic ligand ${ }^{20}$}

Recrystallisation of the bluish-green solid (vide supra), obtained from oxygenation of $\left[\mathrm{Cu}_{2}\left(\mathrm{~L}^{\mathrm{mac}}\right)\left(\mathrm{CH}_{3} \mathrm{CN}\right)_{2}\right]\left[\mathrm{ClO}_{4}\right]_{2}(\mathbf{1 c})$, from $\mathrm{CH}_{3} \mathrm{CN} /\left(\mathrm{C}_{2} \mathrm{H}_{5}\right)_{2} \mathrm{O}$ afforded a blue crystalline solid $\left[\mathrm{Cu}_{2}\left(\mathrm{~L}^{\mathrm{mac}}-\mathrm{O}\right)(\mathrm{OH})\right]\left[\mathrm{ClO}_{4}\right]_{2} \cdot 2 \mathrm{H}_{2} \mathrm{O}(\mathbf{2 c})$. In the $\mathrm{UV}-\mathrm{V}$ is spectrum $\left(\mathrm{CH}_{3} \mathrm{CN}\right.$ solution) this compound exhibits a visible band at $591 \mathrm{~nm}$ and an intense band at $352 \mathrm{~nm}$ (table 1). The former is due to a $d$ - $d$ transition and the latter is due to a phenolate-to-copper(II) charge-transfer transition. Thus we observe that due to inherent strain associated with the present macrocyclic ligand, the oxygen insertion onto one of the arene rings is accompanied by the hydrolysis of the macrocyclic ligand (figure 5).

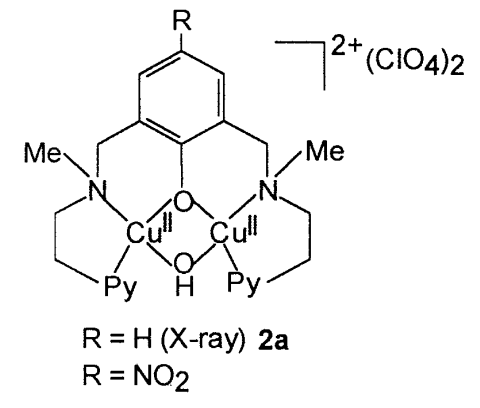

Figure 3. Schematic structures of $\left[\mathrm{Cu}_{2}(\mathrm{~L}-\mathrm{O})(\mathrm{OH})\right]\left[\mathrm{ClO}_{4}\right]_{2} \quad$ (2a) and $\left[\mathrm{Cu}_{2}\left(\mathrm{~L} \Varangle(\mathrm{OH})_{2}\right]\left[\mathrm{ClO}_{4}\right]_{2}(\mathbf{2 b})\right.$.

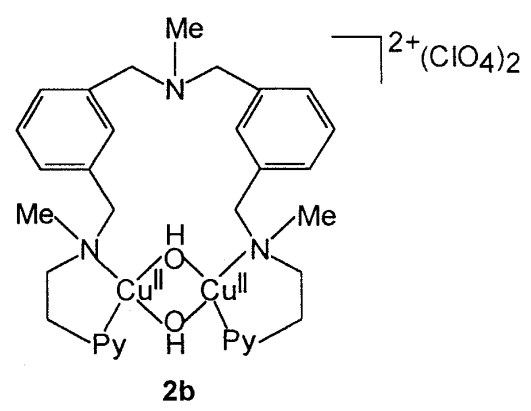



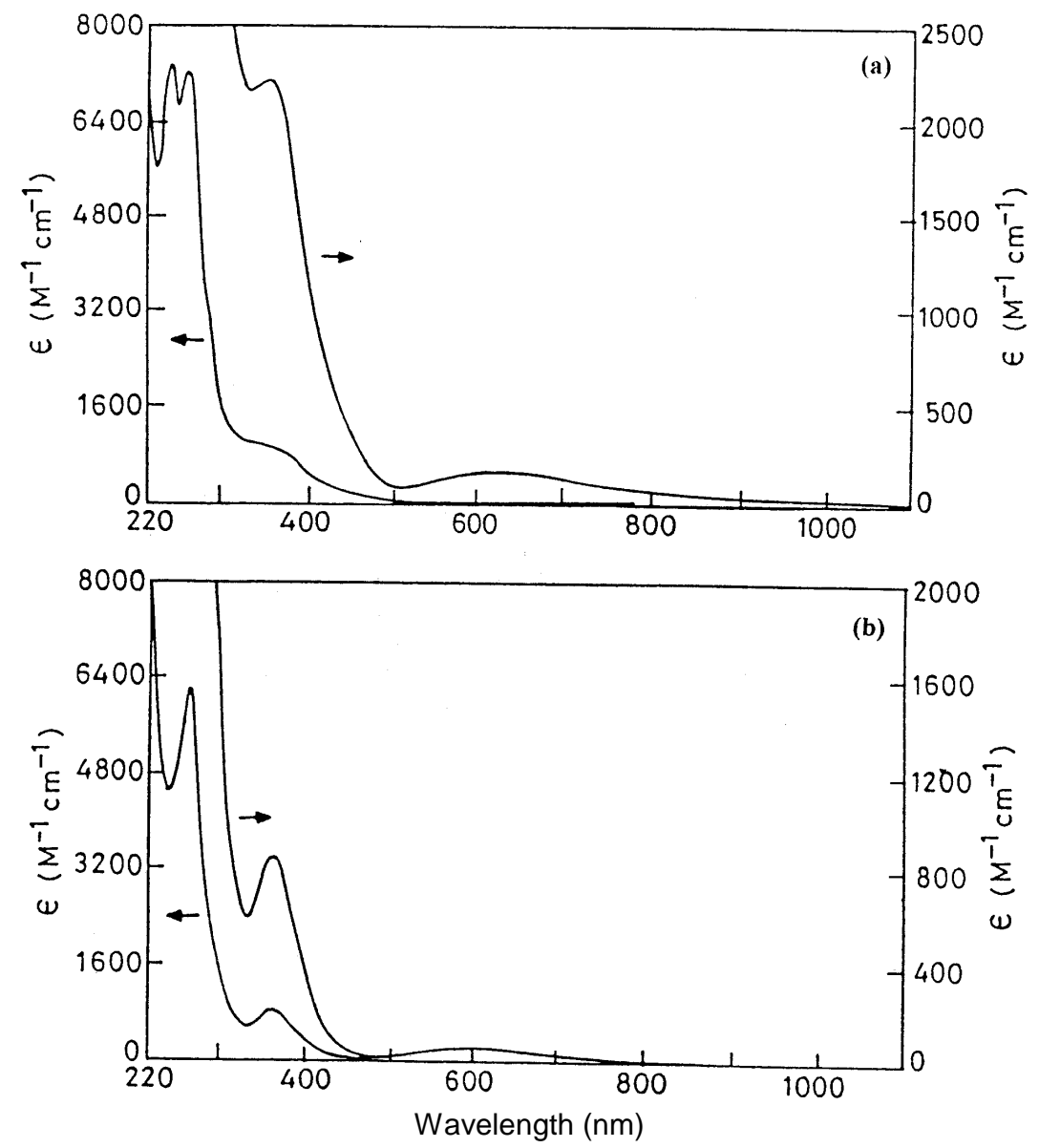

Figure 4. Electronic absorption spectra of (a) $\left[\mathrm{Cu}_{2}(\mathrm{~L}-\mathrm{O})(\mathrm{OH})\right]\left[\mathrm{ClO}_{4}\right]_{2}(\mathbf{2 a})$ and $(\mathbf{b})$ $\left[\mathrm{Cu}_{2}\left(\mathrm{~L} \Varangle(\mathrm{OH})_{2}\right]\left[\mathrm{ClO}_{4}\right]_{2}(\mathbf{2 b})\right.$ in $\mathrm{CH}_{3} \mathrm{CN}$.

\subsection{Magnetism of dicopper(II) complexes ${ }^{19,20}$}

We have studied the temperature-dependent (25-300 K) magnetic susceptibility measurements of structurally characterized phenoxo-/hydroxo-bridged copper(II) complex $\left[\mathrm{Cu}_{2}(\mathrm{~L}-\mathrm{O})(\mathrm{OH})\right]\left[\mathrm{ClO}_{4}\right]_{2} \quad$ (2a) and bis(hydroxo)dicopper(II) complex $\left[\mathrm{Cu}_{2} \mathrm{~L}(\mathrm{OH})\right]\left[\mathrm{ClO}_{4}\right]_{2}(\mathbf{2 b})$. In the absence of the X-ray structural characterisation of $\left[\mathrm{Cu}_{2}\left(\mathrm{~L}^{\mathrm{mac}}-\mathrm{O}\right)(\mathrm{OH})\right]\left[\mathrm{ClO}_{4}\right]_{2} \cdot 2 \mathrm{H}_{2} \mathrm{O}(\mathbf{2})$, we have confirmed the proposed dimeric structure by temperature-dependent magnetic susceptibility measurements. The room-temperature $(300 \mathrm{~K})$ magnetic moments for $\left[\mathrm{Cu}_{2}(\mathrm{~L}-\mathrm{O})(\mathrm{OH})\right]\left[\mathrm{ClO}_{4}\right]_{2}(\mathbf{2 a}),\left[\mathrm{Cu}_{2} \mathrm{~L} \not(\mathrm{OH})_{2}\right]\left[\mathrm{ClO}_{4}\right]_{2}(\mathbf{2 b})$ and $\left[\mathrm{Cu}_{2}\left(\mathrm{~L}^{\mathrm{mac}}-\mathrm{O}(\mathrm{OH})\right]\left[\mathrm{ClO}_{4}\right]_{2} \cdot 2 \mathrm{H}_{2} \mathrm{O}(\mathbf{2 c})\right.$ are quite low $\left(\mathrm{m}_{\mathrm{eff}} / \mathrm{Cu}=1.13 \mathrm{mB}\right.$ for $2 \mathrm{a}, 1.50 \mathrm{mB}$ for $\mathbf{2 b}$ and $1.17 \mathrm{~m}$ for $\mathbf{2 c}$ ), indicative of strong antiferromagnetic exchange coupling between the two copper(II) centres. The data were fitted to the modified Bleaney-Bowers expression in (1) using the isotropic (Heisenberg) exchange Hamiltonian $\left(H=-2 J S_{1} \cdot S_{2}\right)$ 
Table 1. Absorption spectral data for dicopper(II) complexes.

\begin{tabular}{ll}
\hline Compound & \multicolumn{1}{c}{$\mathrm{I}_{\max } / \mathrm{nm}\left(\Theta / \mathrm{M}^{-1} \mathrm{~cm}^{-1}\right)$} \\
\hline$\left[\mathrm{Cu}_{2}(\mathrm{~L}-\mathrm{O})(\mathrm{OH})\right]\left[\mathrm{ClO}_{4}\right]_{2}, \mathbf{2 a}$ & $620(170), 352(2220), 261(7200)$ and \\
& $241(7400)$ \\
$\left.\left[\mathrm{Cu}_{2} \mathrm{L \& (OH}\right)_{2}\right]\left[\mathrm{ClO}_{4}\right]_{2}, \mathbf{2 b}$ & $589(70), 361(990)$ and $264(6240)$ \\
{$\left[\mathrm{Cu}_{2}\left(\mathrm{~L}^{\mathrm{mac}}-\mathrm{O}\right)(\mathrm{OH})\right]\left[\mathrm{ClO}_{4}\right]_{2} \cdot 2 \mathrm{H}_{2} \mathrm{O}, \mathbf{2 c}$} & $591(160), 352(8960), 253(38152)$ and \\
& $207(27470)$ \\
\hline
\end{tabular}<smiles>CC(C)C(=O)O[R20](=O)[O-]</smiles>

Figure 5. Oxygenation of $\left[\mathrm{Cu}_{2}^{\mathrm{I}}\left(\mathrm{L}^{\mathrm{mac}}\right)\left(\mathrm{CH}_{3} \mathrm{CN}\right)_{2}\right]\left[\mathrm{ClO}_{4}\right]_{2}(\mathbf{1 c})$ and the final products.

$$
\mathrm{C}_{\mathrm{M}}=2 N \mathrm{~b}^{2} g^{2} / 3 k T[1+1 / 3 \exp (-2 J / k T)]^{-1}(1-\mathrm{r})+N \mathrm{~b}^{2} g^{2} \mathrm{r} / 2 k T+2 N_{\mathrm{a}},
$$

for two interacting $S=1 / 2$ centres ( $\mathrm{C}_{\mathrm{M}}$ expressed per dimer), $N_{\mathrm{a}}$ is the temperatureindependent paramagnetism (fixed at $60 ¥ 10^{-6} \mathrm{~cm}^{3} \mathrm{~mol}^{-1}$ ), $r$ is the fraction of monomeric impurity. Nonlinear regression analyses were carried out with $J, g$ and $r$ as floating parameters. The best-fit results are in table 2 . The large $2 J$ values of $-440 \mathrm{~cm}^{-1}$ for $\mathbf{2 a},-258 \mathrm{~cm}^{-1}$ for $\mathbf{2 b}$ and $-457 \mathrm{~cm}^{-1}$ for $\mathbf{2 c}$, indicate strong antiferromagnetic coupling between the two copper(II) centres, which occurs via a superexchange mechanism through the phenoxide and hydroxide bridges in $\mathbf{2 a}$ and $\mathbf{2 c}$ and through the two hydroxo bridges in $\mathbf{2 b}$. A closer look at the metric parameters of $\mathbf{2 a}$ and $\mathbf{2 b}$ reveals that in both the complexes, the $\mathrm{Cu} . . \mathrm{Cu}$ distance, the stereochemistry around each $\mathrm{Cu}$ centre and the average $\mathrm{Cu}-\mathrm{OR}-\mathrm{Cu}$ bond angle at the bridging atoms are comparable. The striking difference is that the $\mathrm{Cu}_{2} \mathrm{O}_{2}$ in $\mathbf{2 b}$ deviates more from planarity and is attributable to the fact that two copper(II) ions do not lie in one plane. When the metal ions move into the plane, the overlap between the metal-based $d_{x^{2}-y^{2}}$ orbitals and the oxygen-based $s p^{2}$ hybrid orbitals is increased. Since this S framework represents the dominant pathway for the superexchange mechanism, the enhanced overlap should result in an increase in the antiferromagnetic interaction.

\section{Concluding remarks}

We have demonstrated that aromatic hydroxylation with binuclear copper(I) complexes and dioxygen is not specific to a terminal tridentate $\mathrm{N}$-coordination. In fact, bidentate $\mathrm{N}$-coordination is sufficient enough, whether it is of the open chain type or part of a macrocyclic ligand system, to exhibit tyrosinase-like activity. With the synthesis of an 
Table 2. Exchange coupling constants for the dicopper(II) complexes $\left(H=-2 J S_{1} \cdot S_{2}\right)$.

\begin{tabular}{lccc}
\hline Complex & $J\left(\mathrm{~cm}^{-1}\right)$ & $g$ & $r$ \\
\hline $\left.\mathrm{Cu}_{2}(\mathrm{~L}-\mathrm{O})(\mathrm{OH})\right]\left[\mathrm{ClO}_{4}\right]_{2}, \mathbf{2 a}$ & -220 & $2 \cdot 05$ & $0 \cdot 016$ \\
{$\left[\mathrm{Cu}_{2} \mathrm{~L}(\mathrm{OH})_{2}\right]\left[\mathrm{ClO}_{4}\right]_{2}, \mathbf{2 b}$} & -129 & $2 \cdot 13$ & 0.054 \\
{$\left[\mathrm{Cu}_{2}\left(\mathrm{~L}^{\mathrm{mac}}\right)(\mathrm{OH})\right]\left[\mathrm{ClO}_{4}\right]_{2} \cdot 2 \mathrm{H}_{2} \mathrm{O}, \mathbf{2} \mathbf{c}$} & -229 & $2 \cdot 13$ & $0 \cdot 042$ \\
\hline
\end{tabular}

interesting series of $m$-xylyl-based open-chain ligands $\mathrm{L}\left(\mathrm{L} \phi, \mathrm{L}_{-} \mathrm{NO}_{2}\right.$ and $\mathrm{L} \leqslant$ the oxygenation of the dicopper(I) complexes have been systematically investigated. Rapid decomposition to aromatic ring-hydroxylated product even at $-80^{\circ} \mathrm{C}$ implies that the energy barrier for conversion of intermediate dicopper(II)-peroxo to such species is small. The present studies pinpoint (i) the effect of ligand structure, i.e. a six-membered chelate ring-forming ligand (L) gives rise to aromatic ring hydroxylation whereas a fivemembered chelate ring-forming ligand (L gives only irreversible oxidation, (ii) the effect of appropriate positioning (geometry) of the xylyl ring of the ligand, i.e. compared to $\mathrm{L}$, the failure of the ligand L $\not$ to undergo hydroxylation reaction, and (iii) with a new tetraaza macrocyclic ligand, aromatic hydroxylation in one of the rings has been observed with concomitant partial hydrolysis of the macrocycle. The final dicopper(II) complex has a mphenoxo mhydroxo bridged structure as evidenced from spectroscopic and variable-temperature magnetic studies. Experiments to carefully look at a comparative kinetic data on the solvent dependence and temperature dependence of the aromatic hydroxylation are being planned. Studies on exogenous substrate oxidation are in progress.

\section{Acknowledgements}

Financial assistance received from the Council of Scientific and Industrial Research (CSIR), and the Department of Science and Technology, New Delhi, is gratefully acknowledged. We are indebted to Prof W B Tolman of the University of Minnesota, USA for allowing Dr Samiran Mahapatra to isolate dicopper(I) complexes $\mathbf{1 a}$ and $\mathbf{1 b}$ and carry out their IR, ${ }^{1} \mathrm{H}$ NMR and low-temperature absorption spectroscopic measurements in his laboratory. RG thanks CSIR for the award of a fellowship.

\section{References}

1. Karlin K D and Gultneh Y 1987 Prog. Inorg. Chem. 35219

2. Kitajima N and Moro-oka Y 1994 Chem. Rev. 94737

3. Karlin K D, Kaderli S and Zuberbühler A D 1997 Acc. Chem. Res. 301395

4. Tolman W B 1997 Acc. Chem. Res. 30227

5. Solomon E I, Sundaram U M and Machonkin T E 1996 Chem. Rev. 962563

6. Karlin K D and Tyeklár Z 1994 Adv. Inorg. Biochem. 9123

7. Tyeklár Z and Karlin K D 1989 Acc. Chem. Res. 22241

8. Kitajima N 1992 Adv. Inorg. Chem. 391

9. Sorrell T N 1989 Tetrahedron 453

10. Menif R and Martell A E 1989 J. Chem. Soc., Chem. Commun. 1521

11. Menif R, Martell A E, Squattrito P J and Clearfield A 1990 Inorg. Chem. 294723 
12. Casella L, Gullotti M, Pallanza G and Rigoni L 1988 J. Am. Chem. Soc. 1104221

13. Casella L, Gullotti M, Bartosek M, Pallanza G and Laurenti E 1991 J. Chem. Soc., Chem. Commun. 1235

14. Gelling O J, van Bolhuis F, Meetsma A and Ferringa B L 1988 J. Chem. Soc., Chem. Commun. 552

15. Sorrell T N and Garrity M L 1991 Inorg. Chem. 30210

16. Mahapatra S, Kaderli S, Llobet A, Neuhold Y-M, Palanché T, Halfen J A, Young V G Jr, Kaden T A, Que L Jr, Zuberbühler A D and Tolman W B 1997 Inorg. Chem. 366343

17. Ghosh D, Lal T K, Ghosh S and Mukherjee R 1996 J. Chem. Soc., Chem. Commun. 13

18. Ghosh D, Lal T K and Mukherjee R 1996 Proc. Indian Acad. Sci. (Chem. Sci.) 108251

19. Ghosh D and Mukherjee R 1999 Inorg. Chem. 376597

20. Gupta R and Mukherjee R 1997 Inorg. Chem. Acta 263133 